\title{
並列配置された正方形角柱まわりの有限要素流れ解析と その適用性に関する研究
}

\author{
枝元勝哉 ${ }^{1} \cdot$ 米田昌弘 ${ }^{2}$ \\ ${ }^{1}$ 正会員 工修 川田工業(株) 技術開発本部技術研究室（广 114 東京都北区滝野川 1-3-11） \\ 2 正会員 工博 元川田工業(株)（現 近幾大学理工学部土木工学科）(T 577 東大阪市小若江 3-4-1）
}

\begin{abstract}
本文は，一椂な流れの中に並列配置された正方形角柱を対象として，有限要素法に基づく流れ解析を 実施し, 計算により得られた空気力係数, 静圧分布, フローパターンなどを風洞実駼結果と対比するこ とにより, 数值シミュレーションの適用性とその問題点を検討したものである. その結果, レイノルズ 数 $R e$ を $R e=10^{3}, 10^{4}$ とした 2 次元解析ならびに $R e=10^{3}$ とした 3 次元解析では, 風洞実跧結果と相違して 角柱間に巻込み滑を生しる結果が得られた.これに対し, レイノルズ数を $R e=10^{4}$ とした 3 次元解析では, 風洞実駼結果と同じく巻込み渦を生じない結果が得られ，並列配置された正方形角柱問題に対する 3 次 元解析の有用性とレイノルズ数依存性を明らかにすることができた.
\end{abstract}

Key Words : square cylinders, tandem arrangement, aerodynamic characteristics, wind tunnel test, finite element method, three dimensional flow analysis

\section{1. はじめに}

並列配置された橋梁や斜張橋のダブルケーブル， あるいは2本の塔柱から構成された吊橋の主塔など， 流れの中に複数の構造物 (物体) が近接して設置され た場合，周边の流れ場はそれらの断面形状や相対的 な位置関係によって複雑に変化する1), 2).これらの並 列配置された構造物まわりの流れ状況や，構造物に 作用する空気力特性を詳細に把握しようとした場合, 現状では風洞実験が最も信頼性の高い手段であると 言える.しかしながら，風洞実験では当然のことな がら実験施設が不可欠であり，また，模型の製作か ら実験の終了に至るまで多大の労力と時間および費 用が必要となる. したがって, 風洞実験を補完し得 る合理的な手法に関する検討はきわめて有意義なこ とであり,コンピュータの処理能力 (記憶容量や演算 速度)が飛噼的に発達した現在, 数值流体解析はその 一助になるものとして大いに期待されている.

ところで, 近年における数値流体解析の発展は目 覚ましいものの3), 並列構造物まわりの流れを数値 シミュレーションによって解析した事例は, 単一の 構造物 (断面)に対する事例と比べて, 未だ非常に少 ないのが現状である．このような理由から，著者ら はこれまでに並列円柱を対象とした 2 次元の数值シ
ミュレーションを実施し，数值解析を実施する際の 計算レイノルズ数の問題に加えて, 2 次元解析によ る3次元流れの欠如が, 計算值と実験值の不一致を 招く大きな要因である可能性を指摘してきた ${ }^{4), 5)}$. し かしながら，数值流体解析を風洞実験の代替手段と して設計・検討業務に反映させるためには,さらに多 くの構造系を対象とした解析を実施し，風洞実験と 対比したデータの蓄積が必要であると言える.

そこで, 本文では, 2 本の塔柱から構成された吊 橋などの主塔構造物を念頭に置き，一様な流れの中 に並列配置された正方形角柱を対象として, 有限要 素法に基づく 2 次元および 3 次元の流れ解析を実施 することとした. また，それぞれの流れ解析で得ら れた空気力係数, 静圧分布, フローパターンなどを, 既往の実験結果の 8)に加えて新たに実施した風洞実 験結果と対比することによって, 数值流体解析の適 用性について詳細に検討することとした.その結果, $R e=10^{4}$ なるレイノルズ数のもとで実施した 3 次元解 析結果は, 風洞実験結果との整合性も比較的良好で あり，実用上十分な精度で並列正方形角柱まわりの 流れ特性を再現できるという新たな知見が得られた ことから，ここにその結果を報告する. 


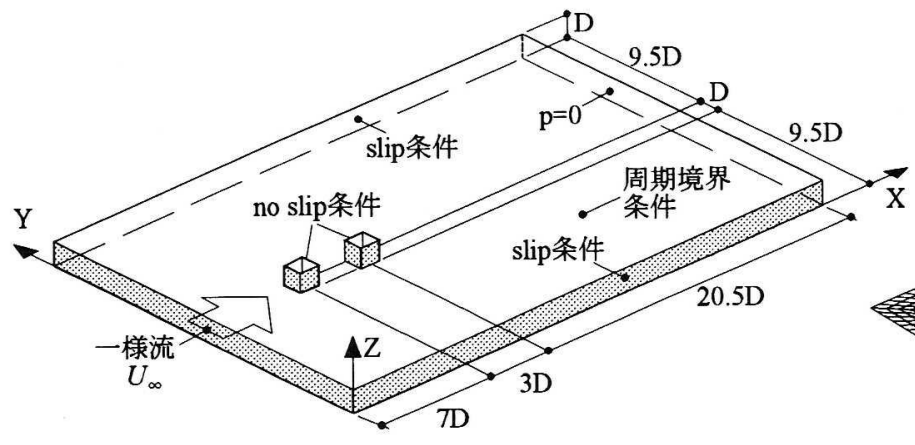

(a) 解析領域一般図

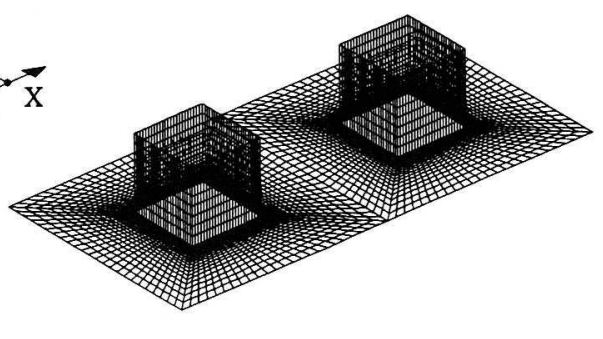

(b) 角柱近傍要素分割図

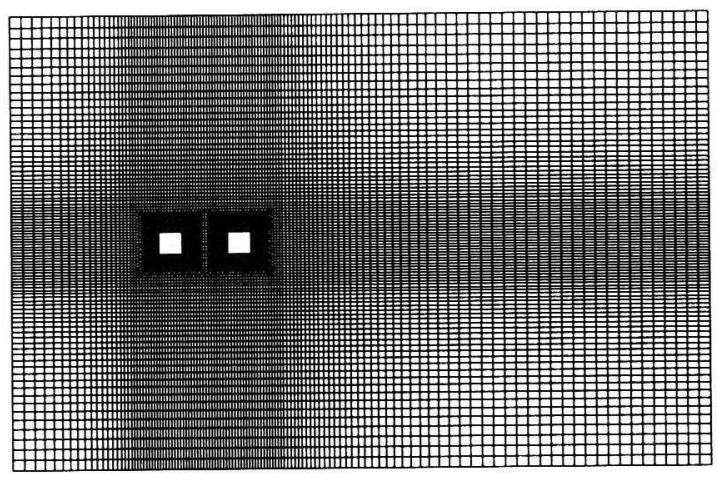

(c) 全体メッシュ (X-Y断面)

图-13 次元並列角柱モデル

\section{2. 解析および実験の概要}

\section{（1）解析手法}

流れは非圧縮粘性流であると仮定し, 図ー1(a)に 示した一様流速 $U_{\infty}$ と角柱幅 D で適切に無次元化さ れた，以下の連続の式と Navier-Stokes 方程式を基礎 方程式として使用する.

$$
\begin{gathered}
\nabla U=0 \\
\frac{\partial U}{\partial t}+U \nabla U+\nabla p-R e^{-1} \nabla^{2} U=F
\end{gathered}
$$

ここに, $U, p, t, F$ はそれぞれ無次元化された流速 ベクトル, 圧力, 時間, および物体力を表す. また, $R e$ はレイノルズ数を表し, $R e=U_{\infty} \mathrm{D} / v(v$ : 動粘性係 数)である. なお, 本研究での解析では, 重力等によ る物体力は無視し得るとの仮定のもとに, 式(2)にお いて $F=0$ と置いている.

本論文では, 解析手法として分離型有限要素法9 を採用するが, さらに, 高レイノルズ数における計 算の安定性を高めるため, 改良 BTD 法 ${ }^{10)}$ による数值 粘性効果を取り入れている. 改良 BTD 法において
は, 計算効率の向上を図るため, 基礎式における時 間方向の離散化に Crank-Nicolson 法を適用する.こ の時, 式(1), (2) は以下のように変形される.

$$
\begin{aligned}
\nabla^{2} p^{n+1 / 2}= & \frac{1}{\Delta t} \nabla U^{n}-\nabla\left(U^{n} \nabla U^{n+1 / 2}-R e^{-1} \nabla^{2} U^{n}\right) \\
\frac{U^{n+1}-U^{n}}{\Delta t} & +U^{n} \nabla U^{n}+\nabla p^{n+1 / 2} \\
& -R e^{-1} \nabla^{2} U^{n+1 / 2}-\frac{\Delta t}{2} U^{n} \nabla\left(U^{n} \nabla U^{n+1 / 2}\right. \\
& \left.+\nabla p^{n+1 / 2}-R e^{-1} \nabla^{2} U^{n+1 / 2}\right)=0
\end{aligned}
$$

ここに, 各変数の添字 $n$ は時刻 $n \Delta t$ の值であること を表す. また， $U^{n+1 / 2}=\left(U^{n+1}+U^{n}\right) / 2$ である. 式(4) の左辺最終項が改良BTD法による数值粘性項である が，括弧内の各項に着目すれば明らかなように，従 来のBTD法で考慮されていた移流項に加えて, さら に圧力項および粘性項の寄与分が付加されている. これにより解の数值的な散逸誤差が軽減される.

式(3)の圧力ポアソン方程式から $p^{n+1 / 2}$ 算出し, こ れを式(4)に代入することにより $U^{n+1}$ を求めるのが 分離型法の一般的な計算手順であるが, 式(3)には未 
表 -1 計算の諸元

\begin{tabular}{l|c|c|c}
\hline \hline \multicolumn{1}{c|}{ パラメータ } & 2 次元計算 & 3 次元計算 & 風洞実験 \\
\hline レイノルズ数 $R e$ & $10^{3}, 10^{4}$ & $10^{3}, 10^{4}$ & $1.3 \sim 6.7 \times 10^{4}$ \\
総節点数 & 15368 & 122944 & - \\
総要素数 & 15064 & 120512 & - \\
最小メッシュ幅 & $0.0035 \mathrm{D}$ & $0.0035 \mathrm{D}$ & - \\
時間刻み $\Delta t$ & 0.02 & 0.02 & $0.005(\mathrm{sec})$ \\
サンプリンク時間 & 200 & 400 & $10(\mathrm{sec})$ \\
\hline \hline
\end{tabular}

知の流速 $U^{n+1 / 2}$ が含まれているため, そのままでは解 くことが出来ず, 式 (4) と連立して解く必要が生じ る. 本研究では, 計算効率の向上を図るため, 式(3) における $U^{n+1 / 2}$ を陽的に $U^{n}$ で近似し, 通常の分離型 法の手順に則った解析を可能とさせている.

式(3)，(4)をもとに重み付き残差方程式を構成し, さらに空間的な離散化を施すことにより，最終的な 有限要素方程式が得られる.

\section{（2）解析モデル}

本研究で対象とした解析モデル (並列正方形角柱モ デル)を図ー1に示す. 図一1 (a)からわかるように, 正方形の一辺の幅を D とした場合，2つの角柱は水 平中心間隔3Dだけ離して固定されている. X-Y 平面 における領域の大きさは30.5D×20D(閉塞率 $5 \%$ )であ り, また, Z方向の領域高さは, 使用したコンピュー タのメモリー制約から 1Dとした. 領域内部は8節点 アイソパラメトリック要素を用いて分割されている が，図一1(b)，(c)に示すように，X-Y平面内におい てはメッシュが密になる不均等分割を施し, 一方, $\mathrm{Z}$ 方向に対しては 8 層に均等分割を施している.

境界条件として, 領域入口にX方向の一様流速を 与える.また, 角柱表面上において no-slip 条件を, 両壁面上において slip 条件をそれぞれ与える.さら に, $Z$ 軸に直角な境界面に対しては周期境界条件を 課した. 式(3)のポアソン方程式を解く際に, 流出境 界面において圧力の基本境界条件が必要とされるが, 計算では $p=0$ として対処している.

なお, 流れ特性に及ぼす 3 次元性の効果を確認す るため, $\mathrm{Z}$ 方向に厚みを持たない 2 次元モデルにお いても同一の計算を実施し，3 次元モデルとの対比 を行った. また, 式(2)におけるレイノルズ数Reを, 計算途中において $R e=10^{3}$ から $10^{4}$ に変更することに より，あわせてレイノルズ数の影響も確認すること とした. 各ケースの最終的な計算諸元を, 次節に示 す風洞実験条件とともに表一1にまとめる.

\section{（3） 風洞実験の概要}

並列正方形角柱に関する風洞実験は岡島ら ${ }^{6}$ に よって実施されているが，本研究では解析結果との より詳細な比較・対比を目的として, 新たに一様流中 の風洞実験を実施することとした.使用した風洞は， 当社所有の水平回流式ゲッチングン型風洞であり， 測定洞の寸法は幅 $2 \mathrm{~m} \times$ 高さ $2.5 \mathrm{~m}$ である. また, 測定 洞の乱れ強さは $0.3 \%$ 以下にある. 実験模型として, 辺長が $\mathrm{D}=100 \mathrm{~mm}$ の木製正方形角柱を 2 体製作し，水 平中心間隔が 3D でそれぞれに高低差を生じないよ うに，専用の治具を用いて流路内に固定した．角柱 表面上には28点(7点辺)の圧力孔を設け, $R e=1.3 \times 10^{4}$, $2.7 \times 10^{4}, 6.7 \times 10^{4}$ なる 3 種類のレイノルズ数のもとで, 静圧分布 $C_{P}$, 抗力係数 $C_{D}$ ならびに揚力の卓越周波数 $f_{L}$ を測定した.

\section{3. 解析結果と考察}

\section{（1）計算による流れの変动特性}

並列正方形角柱まわりの流れ特性を把握するため, 2 次元および 3 次元の有限要素解析をそれぞれ実施 し, 下流側角柱における抗力係数 $C_{D}$ と揚力係数 $C_{L}$ の 時刻歷変動を算出した. 2次元モデルと3次元モデル による解析結果をそれぞれ比較して图一2，3に示 す. なお, 計算に際して, 無次元時刻 200 までは2 次 元解析を実施し，これ以降は無次元時刻 200 での結 果を初期値として, 2次元あるいは3次元モデルによ る継続計算を実施している．また，レイノルズ数の 影響を調べるために，無次元時刻 $200 〜 400$ までは $R e=10^{3}$ とし, さらにこの $R e=10^{3}$ の途中計算結果を初 期値として, 無次元時刻 $400 \sim 800$ までは $R e=10^{4}$ に 変更して計算を実施した。

图一2からわかるように, レイノルズ数を $R e=10^{3}$ (無次元時刻 $200 \sim 400$ の範囲)に設定した 2 次元お よび3次元解析結果において, 抗力係数 $C_{D}$ はそれぞ れ同程度に変動しており, 両者の結果に顕著な差異 は認められない.すなわち, Re=103 なるレイノルズ 数では， 3 次元解析を実施しても流れの状況は基本 的に 2 次元性が保持されたままの状態であると推察 される.これに対し, $R e=10^{4}$ なるレイノルズ数 (無次 元時刻 400 以降の範囲) では, 両者の結果に明確な差 違を生じている.すなわち, 3 次元計算では, 無次元 時刻 400 を境として抗力係数 $C_{D}$ の変動が小さくなり 始め, さらに無次元時刻 500 を少し越えた時点で, 変 動中心がマイナス側にシフトする現象が認められる. それゆえ, 3 次元計算結果はレイノルズ数に大きく 依存し, 対象とした並列正方形角柱においては, 


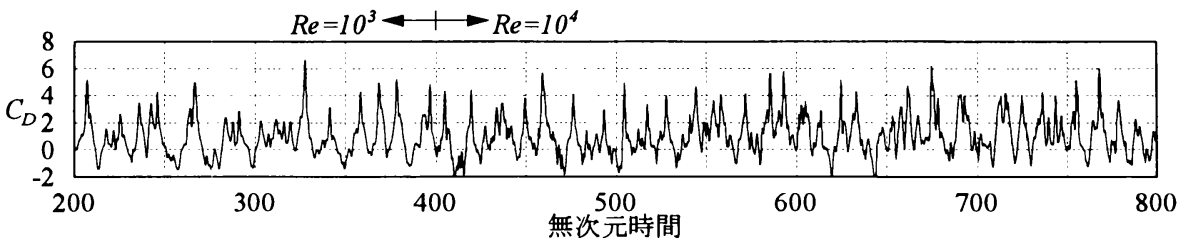

(a) 2 次元計算

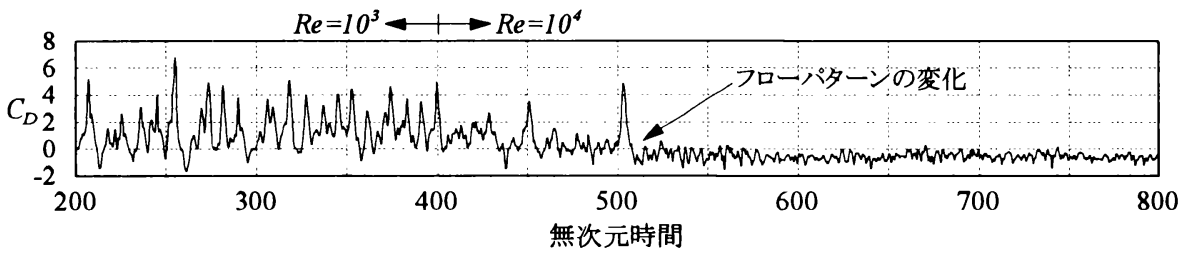

(b) 3 次元計算

図-2 下流側角柱における抗力係数 $C_{D}$ の時刻歷

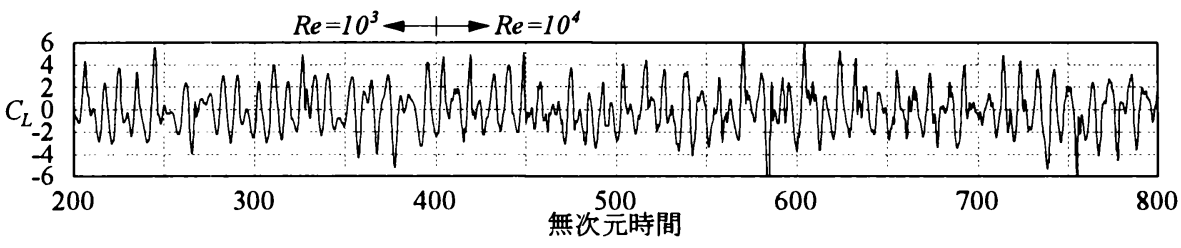

(a) 2 次元計算

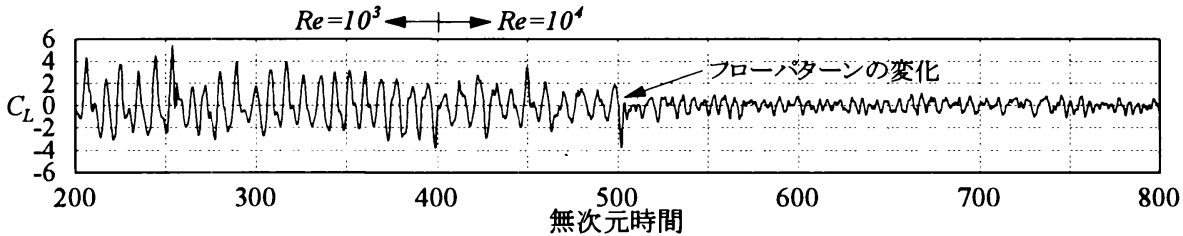

(b) 3 次元計算

図-3 下流側角柱における揚力係数 $C_{L}$ の時刻歷

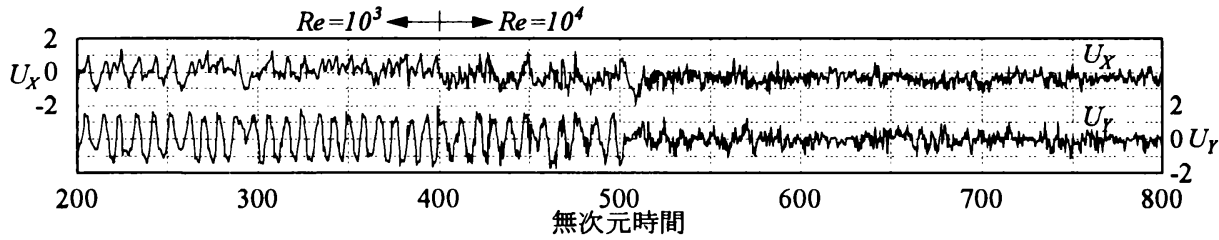

(a) $\mathrm{X}, \mathrm{Y}$ 方向

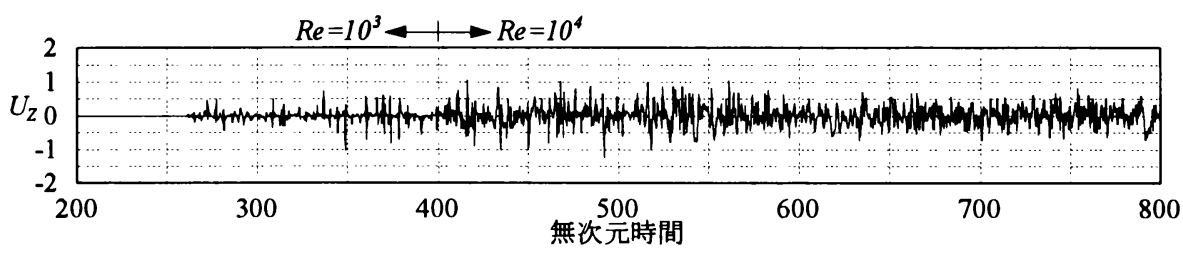

(b) Z方向

図-4 並列角柱中間点における速度べクトル $U$ の成分時刻歴（計算値） 


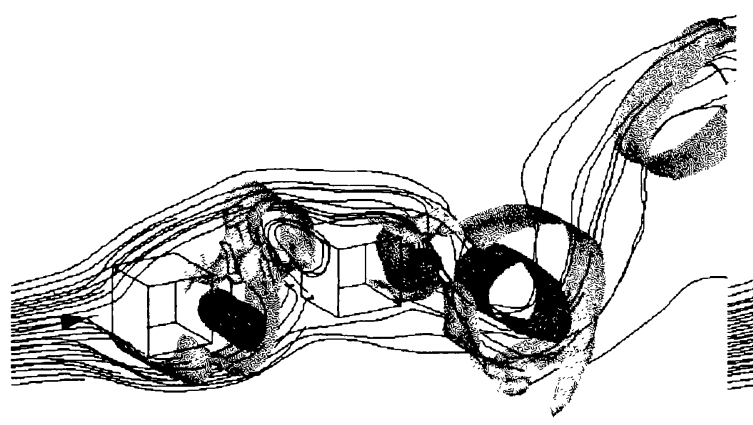

(a) $R e=10^{3}$

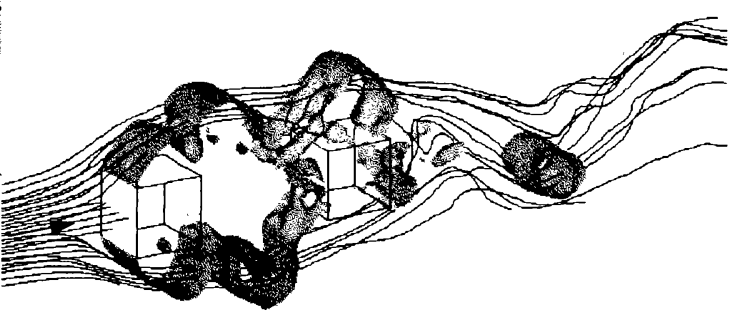

(b) $R e=10^{4}$

図-5 瞬間的な圧力等值面および流線の比較（3 次元計算）

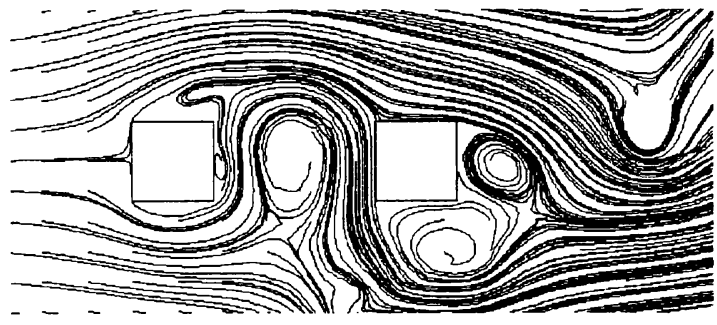

(a) 2 次元計算 $\left(R e=10^{4}\right)$

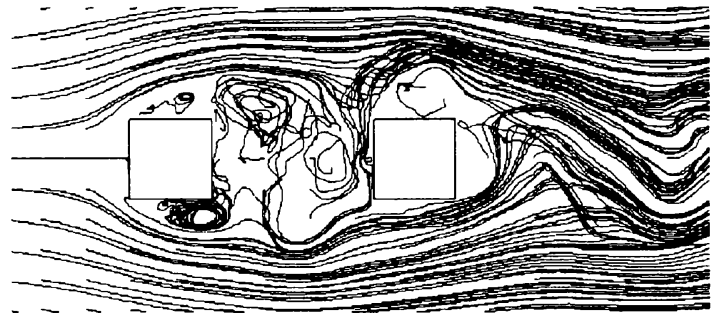

(b) 3 次元計算 $\left(R e=10^{4}\right)$

図一6 瞬間的な流線の比較 (X-Y 断面)

イノルズ数が $R e=10^{3}$ から $R e=10^{4}$ に増加することに よって, 角柱周辺のフローパターンが大きく変化し たと考えられる.

次に, 図一3からわかるように, $R e=10^{3}$ なるレイ ノルズ数 (無次元時刻 $200 〜 400$ の範囲)のもとで得 られた 3 次元計算の揚力係数 $C_{L}$ は, 2 次元計算結果 よりもいく分変動が小さくかつ規則的ではあるもの の, $R e=10^{3}$ なるレイノルズ数においては, 基本的に 両者の結果に顕著な差異は認められないと言える. これに対し, レイノルズ数を $R e=10^{4}$ とした場合（無 次元時刻が 400 以降の範囲）には, 揚力係数 $C_{L}$ の変 動が大幅に減少する結果となっており， $C_{D}$ の場合と 同じく, レイノルズ数が $R e=10^{3}$ から $R e=10^{4}$ に増加す ることによって, フローパターンが大きく変化した ものと考えられる.

以上の結果に加えて, 上・下流側角柱の中間点 $(\mathrm{X}-$ Y平面上)にも着目し, この点での各軸方向 $(\mathrm{X}, \mathrm{Y}, \mathrm{Z}$ 方 向)の速度変動を 3 次元解析で算出することとした. 解析結果を図一4に示す. 図一4 (a) と図一3(b) を対 比すればわかるように, レイノルズ数が $R e=10^{3}$ (無 次元時刻 $200 \sim 400$ の範囲) の場合, $\mathrm{Y}$ 方向の速度 $U_{Y}$ (揚力方向の速度成分) と 3 次元計算の揚力係数 $C_{L}$ と の間には密接な相関関係が認められる.このことは, 角柱間を横切る流れが下流側角柱の空気力特性を支 配していることを示唆する. 一方，図一4(b)に示し

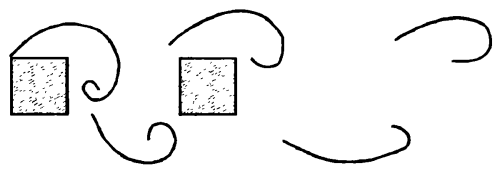

(a) 角柱間に巻込みを生じるパターン

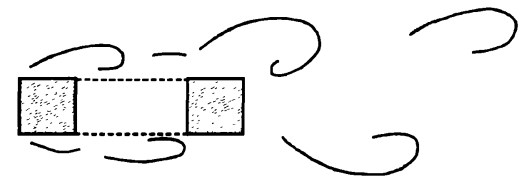

(b) 角柱間に巻込みを生じないパターン

図ー7 並列角柱まわりのフローパターンの分類》

た $Z$ 軸方向の速度 $U_{z}$ は, 変動自体に明確な規則性は 認められず, また, $R e=10^{3}$ なるレイノルズ数では変 動の程度も非常に小さいと言える.これに対し， $R e=10^{4}$ なるレイノルズ数 (無次元時刻 400 以降の範 囲)では, $R e=10^{3}$ の場合と比べて $U_{z}$ が大きく変動し ており，Z軸方向への流れが活発に生じていると考 えられる.ところで，図ー2，3に示したように，2 次元計算ではレイノルズ数を変化させても 3 次元計 算結果で見られたような変動特性の大幅な変化は認 められない. それゆえ， 2 次元解析では反映できな いZ 軸方向への移流搪散効果が, 3 次元解析におい て変動特性の大幅な変化(フローパターンの変化)を 


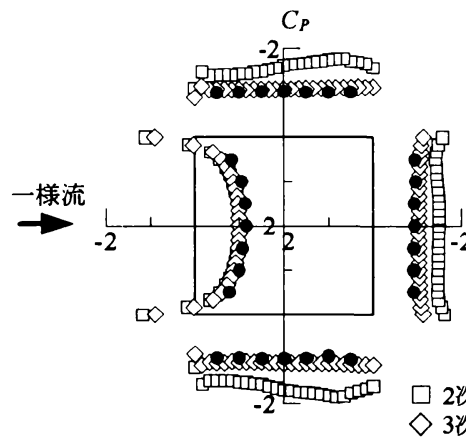

（上流側）

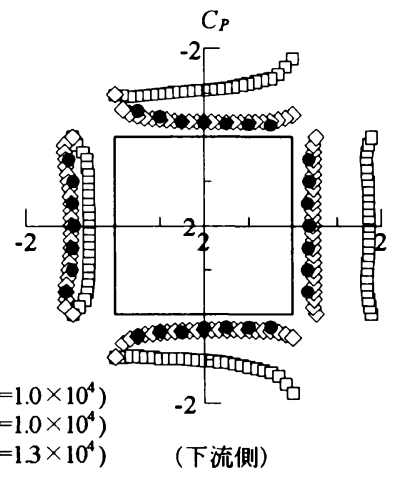

(下流側)

図-8 並列角柱における表面圧力係数分布の比較

表-2 計算および実験による各係数の比較

\begin{tabular}{|c|c|c|c|c|c|c|}
\hline \multirow{2}{*}{ 保数 } & \multicolumn{2}{|c|}{ 計算值 $\left(R e=1.0 \times 10^{4}\right)$} & \multicolumn{3}{|c|}{ 著者らの実験値 } & \multirow{2}{*}{$\begin{array}{c}\text { 岡島らの実験值 } \\
\text { ( ) } \\
R e=3.0 \times 10^{4}\end{array}$} \\
\hline & 2 次元モデル & 3 次元モデル & $R e=1.3 \times 10^{4}$ & $R e=2.7 \times 10^{4}$ & $\operatorname{Re}=6.7 \times 10^{4}$ & \\
\hline 抗力係数 (上流側) $C_{D W}$ & 2.129 & 1.723 & 1.796 & 1.790 & 1.793 & 1.75 \\
\hline 抗力係数 (下流側) $C_{D L}$ & 1.048 & -0.583 & -0.580 & -0.622 & -0.664 & -0.625 \\
\hline 背圧係数 (上流側) $C_{P B W}$ & -1.483 & -1.022 & -0.932 & -0.946 & -0.964 & -0.9 \\
\hline よどみ圧(下流側) $C_{P F Z}$ & -0.587 & -0.989 & -0.923 & -1.011 & -1.035 & -0.967 \\
\hline 背圧係数 (下流側) $C_{P B L}$ & -1.726 & -0.452 & -0.371 & -0.395 & -0.406 & -0.383 \\
\hline ストローハル数 $\quad S t$ & 0.105 & 0.118 & 0.102 & 0.115 & 0.116 & 0.123 \\
\hline
\end{tabular}

生む直接的な原因になっているものと推察される.

\section{（2）並列角柱周辺のフローパターン}

前節で示したように，3 次元解析においては，レ イノルズ数を $R e=10^{3}$ から $10^{4}$ に增加させると抗力・場 力特性が急激に変化する. そこで, この現象を把握

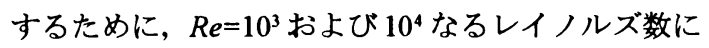
おける角柱近傍の 3 次元的な流れの状態を, 瞬間的 な圧力の等值面および流線分布の形で可視化するこ ととした. その結果を図一5に示す. また, これと同 時に, 2次元および3次元計算による流れ特性の違い を明らかにするため, レイノルズ数 $R e=10^{4}$ におけ る両者の瞬間的な流線の分布をX-Y断面内で可視化 した.その結果を図一6に示す。

図一5(a) から, $R e=10^{3}$ の 3 次元計算においては, 角柱間および下流側角柱背後に 2 次元性の強い渦が 形成されていることがわかる.また，これに伴って， 流線も角柱間および下流側角柱背面に巻き込まれて いることが理解される.このような流れの様相は, 图一6 (a)に示した 2 次元計算の結果 $\left(R e=10^{4}\right)$ と基本 的には同じであり, したがって, レイノルズ数を $R e=10^{3}$ とした場合には, 3 次元計算を用いても 2 次 元の結果とほぼ同じ傾向を示し, 前述したように,
角柱間人の巻込みに従って揚力係数 $C_{L}$ も $\mathrm{Y}$ 方向の速 度変動 $U_{z}$ と同じ挙動を示したと考えられる.

一方, 图一5(b)からわかるように,レイノルズ数 を $R e=10^{4}$ とした 3 次元計算では, $R e=10^{3}$ なる場合に 認められた角柱間および下流側角柱背後の大きな渦 が消散しており，これに伴い流線の巻込みも無く なっている. また, 同じ 3 次元計算結果を X-Y 断面 内の流線として捉えた図一6(b) からわかるように, 角柱間には一種の死水領域的な弱い流れの循環領域 が形成されており, 図一4(a)において $U_{x} U_{Y}$ の変動 が小さくなった現象を裏付けている.

ところで, 武内らク, 松尾ら ${ }^{8)}$ は, 並列角柱を対象 とした風洞実験結果から, 両角柱周りには角柱間隔 に依存して图ー7に示すような2つのフローパター ン(角柱間に巻込みを生じる場合と生じない場合)が 存在することを明らかにしており，さらに本研究で 対象とした中心間隔3Dなる並列角柱の場合には, 角 柱間に巻込みを生じないフローパターンが卓越する と報告している. 上述したように, 本研究で実施し た解析では, 3 次元モデルを使用し, その上でレイ ノルズ数を $R e=10^{4}$ とした場合にのみ既往の風洞実験 結果と同じフローパターンが認められた.すなわち, 水平間隔3Dの並列正方形角柱問題を2次元モデルに 
より検討した場合，レイノルズ数は現象を左右する 一義的なパラメータとはなり得なかった．したがっ て, 本研究のようにフローパターンが流れ特性に大 きな影響を及ぼす問題においては, 流れの 3 次元性 を考虑した上でレイノルズ数を変化すべきであると 言える.

\section{（3）平均流れ特性の比較}

本節では, 2次元および3次元解析により算出され た角柱表面の静圧分布および抗力係数・ストローハル 数等の平均流れ特性を, 著者らが新たに実施した風 洞実験結果および既往の実験結果と対比する.

图ー8は, $R e=10^{4}$ なるレイノルズ数で計算した角 柱表面の平均圧力倸数 $C_{p}$ の分布について, 風洞実験 値 $\left(R e=1.3 \times 10^{4}\right)$ と比較した結果を示したものである. 図一8から，2次元計算結果は，3次元の計算結果や 風洞実験結果と比較して, 上・下流側角柱ともに大き な側面圧および背面圧分布を示していることがわか る.これは前節で述べたフローパターンの相違に起 因すると考えられる. 一方, これに対して 3 次元計 算結果 $\left(R e=1.0 \times 10^{4}\right)$ は, 風洞実験結果と比較すれば わかるように，定量的にも非常に良く実験值の平均 特性を再現していると言える.

最後に, 本文で実施した 2 次元と 3 次元の計算結 果を, 著者らが新たに実施した風洞実験結果および 岡島らの実験結果のと合わせて表一2にまとめる. な お, 表中に示したストローハル数 Stは, 厳密には後 流の速度変動から実測すべきであるが, 著者らの実 験では下流側角柱に作用する揚力変動の卓越周波数 $f_{L}$ から算定した值を記している.

表一2から明らかなように, 2次元解析ではいずれ の係数も 3 次元解析結果 $\left(R e=10^{4}\right)$ や風洞実験值と大 きく相違する結果を示している. これに対し, 3 次 元解析では, いずれの係数も風洞実験值と比較的良 い整合性を示していることがわかる. また, 上流側 角柱の背圧係数 $C_{P B W}$ と下流側角柱のよどみ圧 $C_{P F L}$ は ほぼ等しい値を示しているが，これは両角柱間に死 水領域が形成されているとした前節の考察を裏付け ている.なお, 背圧係数 (上流側) $C_{P B W}$, よどみ圧(下 流側) $C_{P F L}$ ならびに背圧係数 (下流側) $C_{P B L}$ において, 3 次元計算結果の方が実験值より幾分大きめの値を 与えているが，これは 3 次元モデルにおける軸方向 の幅および分割数が十分ではなく， 3 次元的な移流 拡散現象を十分な精度では再現出来なかったためと 考えている. また, 同様な理由で, ストローハル数 $S t$ も実験値に比べると幾分大きな值を示したと考え られる.

\section{4. まとめ}

本論文は, 並列正方形角柱 (中心間隔3D) を対象と した 2 次元および 3 次元有限要素流れ解析を実施す るとともに, 風洞実験結果との対比から数值流体解 析の適用性を検討したものである. 得られた主要な 結果を，以下にまとめる.

(1) レイノルズ数を $R e=10^{3}$ とした 2 次元および 3 次元 流れ解析を実施した結果, 算出されたそれぞれの抗 力および揚力特性には顕著な差異は認められなかっ た.

(2)これに対し,レイノルズ数を $R e=10^{4}$ とした場合, 2 次元および 3 次元解析で得られた抗力および揚力 の変動特性には明確な差異が認められた.これは, 3 次元解析ではレイノルズ数が $R e=10^{3}$ から $R e=10^{4}$ に 增加することによって, 角柱周辺のフローパターン が大きく変化したことに起因する.

(3) $R e=10^{4}$ なるレイノルズ数で実施した 3 次元解析結 果は, Z 軸方向の幅および分割数が比較的粗いにも かかわらず,風洞実験結果との整合性は良好であり， 実用上十分な精度で並列正方形角柱まわりの平均流 れ特性を再現できる.

本研究によって, 並列角柱問題における 3 次元計 算の有用性を明らかにすることができたと考えてい るが, 今後は有限要素のモデル化と解析精度の関係, および他の角柱配置に対する適用性についても研究 していく所存である.

なお，本研究を実施するにあたり，中央大学の川 原睦人教授が開発されたプログラムを使用させてい ただきました. 先生には, 本文をまとめる際にも貴 重な御助言を賜り,心より厚く御礼を申し上げます.

\section{考考文献}

1）白土博通: 複数棒造物の空気力学的举動に関する研究, 京都大学学位論文, 1988 年 8 月.

2) Shiraishi, N., Matsumoto, M., and Shirato, H. : On aerodynamic instabilities of tandem structures, Journal of Wind Engineering and Industrial Aerodynamics, 23, Elsevier Science Publishers B.V., pp.437-447, 1986.

3) たとえば, 山田均, 野村卓史 : 数值解析技術の最前線 (その2), 風のシミュレーション, 土木学会誌, Vol.79, No.7, pp.46-54, 1994 年 7 月.

4) 枝元勝哉, 米田昌弘, 川原睦人: 静止時および强制加 振時における並列円柱まわりの流れの有限要素解析, 棬造工学論文集, Vol.41A, pp.369-376, 1995 年 3 月.

5）枝元勝哉, 米田昌弘, 川原睦人: 2 次元並列円柱まわり の流れの有限要素解析とその適用性, 第 13 回風工学シ 
ンポジウム論文集, pp.549-554, 1994 年 12 月.

6) 岡島 厚, 木綿隆弘 : 直列配置の 2 矩形柱の空力静特 性, 構造工学論文集, Vol.36A, pp.849-857, 1990年3月.

7) 武内隆文, 松本 勝, 白石成人 : タンデム配列ブラッ フ角柱に発現する滑励振に関する研究, 第 12 回風工学 シンポジウム論文集，pp.375-380，1992年 12 月.

8）松尾日出男，西山博之，小野謙二，吉居 貢，宮田正 信, 大屋裕二: くいちがい配置された複数矩形柱まわ りの流れ, 第 10 回風工学シンポジウム論文集, pp.91-

96,1988 年 12 月.
9) Hayashi, M., Hatanaka, K., and Kawahara, M. : Lagrangian finite element method for free surface Navier-Stokes flow using fractional step method, International Journal of Numerical Methods in Fluid, Vol.13, pp.805-840, 1991

10）丸岡 晃, 太田真二, 平野廣和, 川原睦人 : 同時補間 を用いた陰的有限要素法による非圧縮粘性流れの解析, 構造工学論文集, Vol.43A, pp.383-394, 1997 年 3 月.

\title{
APPLICABILITY OF FINITE ELEMENT ANALYSIS TO FLOW AROUND TWO SQUARE CYLINDERS IN TANDEM ARRANGEMENT
}

\author{
Katsuya EDAMOTO and Masahiro YONEDA
}

\begin{abstract}
Finite element analyses for flow around two square cylinders in tandem arrangement were performed with two and three dimensional numerical models. The computational flow characteristics were compared with wind tunnel results in terms of drag coefficient, pressure coefficient, and flow pattern, then the applicability of the numerical simulation to the structures in tandem was studied. It has been reported that flow patterns around two rectangular columns in tandem can be classified into two modes. One of the modes, where the Kármán vortex is not formed between the cylinders, should prevail with the column spacing used in this paper, and it could be adequately represented only by the three dimensional simulation at $R e=10^{4}$. As a result, the computed aerodynamic characteristics in this case agreed well with the experimental results, and the effectiveness of three dimensional computation and Reynolds number were confirmed.
\end{abstract}

